УДК 656.073.28

DOI 10.31375/2226-1915-2020-1-86-98

В.Ю. Смрковська к.т.н., доцент кафедри «Управління логістичними системами і проектами» Smrkovskaia@gmail.com ORCID: 0000-0003-4515-5236

Одеський наиіональний морський університет, Одеса, Украӥна

ЧОТИРИРІВНЕВА ДЕКОМПОЗИЦІЯ СИСТЕМ ДОСТАВКИ ВАНТАЖІВ 3 ВИЗНАЧЕННЯМ ОСНОВНИХ КРИТЕРІЇВ ФУНКЦІОУВАННЯ

Анотація. Прагнення до формування систем доставок визначилося у світових торгової транспортної сферах лише в останнє двадиятиріччя. Головною причиною активізації даного процесу стала можливість отримання економії на иіні товарів. При швидкому зростанні обсягів споживання та насичення споживчих ринків різноманітними товарами за рахунок уніфікації $і$ стандарти зачії продукиії, виробничих процесів, технологій були досягнуті мінімальні значення собівартості виробленої продукиії. Подальше зниження виробничих витрат стало практично неможливим. У цих умовах головним джерелом зниження ціни товарів можуть бути лише транспортні витрати. Крім того, вантажсовіправниками все частіме стало висуватися вимога обгрунтування логіки виконання транспортних та інших операцій з організації руху товарних потоків, щчо в кінцевому підсумку стало критерісм формуються регіональних, національних i міжнародних систем доставки, у створенні яких знайшов вираз інтеграчійний механізм управління.

Тобто, найбільшого успіху в ринковій економіці досягають ті компанії, всі виробничі дї яких спрямовані на задоволення вимог вантажовідправників. Боротьба за отримання кожного нового замовника обумовлює потребу в гнучких виробничих процесах, здатних швидко реагувати на кон'юнкту py nonumy.

Очевидно, шо зазнали зміни, як назва, так $i$ суть процесу організації перевезення вантажів. Організачія системи доставки - якісно нова послуга для вітчизняного вантажовідправника. На наш погляд, основні причини, щуо послужили передумовами для трансформачії транспортування вантажу в систему доставки, ие: млень;

- розвиток безперевантажувальних повідо-

- розиирення прав і функиій експедитора;

- еволюиія організаційних структур підприEMcmв.

Ключові слова: система доставки, опис, елементи, функиіі, параметри.
УДК 656.073.28

DOI 10.31375/2226-1915-2020-1-86-98

В.Ю. Смрковская

к.т.н., доцент кафедры

«Управление логистическими системами проектами»

Одесский начиональный морской университет,

Одесса, Украина

ЧЕТЫРЕХУРОВНЕВАЯ ДЕКОМПОЗИЦИЯ СИСТЕМ ДОСТАВКИ ГРУЗОВ С ОПРЕДЕЛЕНИЕМ ОСНОВНИХ КРИТЕРИЕВ ФУНКЦИОНИРОВАНИЯ

Аннотация. Стремление к формированию систем доставок определилось в мировых торговой и транспортной сферах лишь в последнее двадиятилетие. Главной причиной активизации данного процесса стала возможность получения экономии на иене товаров. При быстром росте объемов потребления и насыщения потребительских рынков разнообразными товарами за счет унификаиии $u$ стандартизаџии продукции, производственных проиессов, технологий были достигнуты минимальные значения себестоимости производимой продукиии. Дальнейшее снижение производственньх издержек стало практически невозможным. В этих условиях главным источником снижения иень товаров могут быть только транспортные затраты. Кроме того, грузоотправителями все чаме стало выдвигаться требование обоснования логики выполнения транспортных и других операџий по организации движения товарных потоков, что в конечном итоге стало критерием формируюшихся региональных, начиональных и международных систем доставки, в создании которых нашел выражение интеграционный механизм управления.

То есть, наибольшего успеха в рыночной экономике добиваются те компании, все производственные действия которых направлены на удовлетворение требований грузоотправителей. Борьба за получение каждого нового заказчика обуславливает потребность в гибких производственных про-цессах, способных быстро реагировать на конъюнк-туру спроса.

Очевидно, что претерпели изменения, как название, так и суть проиесса организаиии перевозки грузов. Организачия системь доставки качественно новая услуга для отечественного грузоотправителя. На наш взгляд, основные причины, послужившие предпосылками для трансформации транспортировки груза в систему доставки, это:

- развитие бесперегрузочных сообщений;

- расширение прав и функиий экспедитора;

- эволючия организационных структур предприятий.

Ключевые слова: система доставки, описание, элементы, функции, параметры.

(C) Смрковская В.Ю., 2020 
UDC 656.073.28

DOI 10.31375/2226-1915-2020-1-86-98

V. Smrkovska

Phd, Senior Lecturer, Department of Logistics Systems and Projects Management e-mail: Smrkovskaia@gmail.com ORCID: 0000-0003-4515-5236

Odessa National Maritime University, Odesa, Ukraine

\title{
FOUR-LEVEL DECOMPOSITION OF CARGO DELIVERY SYSTEMS WITH THE DEF- INITION OF BASIC FUNCTIONING CRITERIA
}

\begin{abstract}
The desire for the formation of delivery systems was determined in the global trade and transport sectors only in the last twenty years. The main reason for the activation of this process was the possibility of obtaining less price of goods. With the rapid growth of consumption and the saturation of consumer markets with various products due to the unification and standardization of products, production processes, technologies, the minimum values of the cost of production were achieved. A further reduction in production costs has become impossible. Under these, the main source of reducing the price of goods can only be transport costs. In addition, shippers increasingly came up with the requirement to justify the logic of transportation and other operations to organize the goods movement, which ultimately became a criterion for the emerging regional, national and international delivery systems, in the creation of which the integration management mechanism found expression.
\end{abstract}

That is, the greatest success is achieved by those companies whose all production activities are aimed at meeting the requirements of shippers. The struggle to receive each new customer necessitates flexible production processes that can quickly respond to demand.

In this case, cost reduction is achieved by coordinating the structural units of the company from the moment of receiving the order to the moment of its execution. Ideally, all production operations should be fully integrated (interchangeable and interdependent) and should constitute a single process for managing material, information and other types of flows.

Organization of an integrated delivery system for all participants in transportation allows you to coordinate the actions of all parts of the transport and distribution chain of any transportation, provide tight control over freight flows, simplify the procedures for processing customs, transportation and other documents, and, therefore, make the process of cargo delivery fast, efficient and mutually beneficial.

Obviously, both the name and the essence of the process of organizing the transportation of goods have undergone changes. Organization of the delivery system is a qualitatively new service for the domestic shipper. In our opinion, the main reasons that served as prerequisites for the transformation of cargo transportation into a delivery system are:

- development of non-reloading connections;

- expansion of rights and functions of a forwarder;

- evolution of organizational structures of enterprises.

Keywords: delivery system, description, elements, functions, parameters.

Постановка проблеми. Система доставки - відносно нове поняття, що з'явилося з переходом України на ринкові стосунки. Під системою доставки розуміють широке коло операцій, що виконуються після виготовлення продукції і до отримання ii споживачем, або наступна стадія 
після виробництва, якщо ці операції $\mathrm{\epsilon}$ продовженням виробничого процесу. Такі операції включають доставку вантажу, складування, зберігання, агрегацію, а також перевезення будьяким видом транспорту. Також, в поняття «доставка вантажів» входять зв'язані операції, такі, як вибір маршруту, розробка графіку руху і технічне обслуговування транспортних засобів [1].

Основна мета організації i функціонування системи доставки швидке, якісне і грамотне переміщення вантажу при якнайповнішому задоволенні вимог клієнтів. Причому вимоги часто можуть суперечити один одному. Наприклад, вимога мінімальних витрат на доставку йде вразріз з вимогою про забезпечення конкретного терміну доставки, оскільки це тягне додаткові витрати на організацію і оперативне управління. Таким чином, наявність одночасно декількох цілей у клієнтів призводить до необхідності рішення багатокритеріальної задачі вибору варіанту системи доставки, оскільки вона дозволяє знаходити компромісне рішення в подібних випадках. Вимогам, що пред'являються до системи доставки, можна поставити у відповідність набір параметрів, які можуть бути як жорстко задані, так і допускаючи різні варіанти, що дає можливість оптимізації одного за рахунок варіювання іншими.

Огляд останніх досліджень та публікацій. Питання організації і управління системами доставки висвітлені в роботах [1-8;10], проте відсутній комплексний опис системи доставки вантажів, який дозволив би чітко визначити, 3 яких елементів вона полягає і які 3 них дозволяють підвищувати рівень якості системи доставки і знижувати витрати шляхом варіювання різними параметрами.

Аналіз літературних джерел показав, що актуальними на сьогоднішній день $\epsilon$ проблеми проектування, організації та оптимізації функціонування систем доставки вантажів - нового напряму в дослідженнях транспортної сфери, який передбачає інтегрований підхід до транспортування вантажу 3 урахуванням інтересів організаторів систем доставки.

Завдання дослідження. $\mathrm{y}$ зв'язку з вищесказаним, метою роботи $\epsilon$ опис системи доставки вантажів, виявлення іiї основних елементів і визначення основних параметрів, по яких відбувається вибір клієнтом одного $з$ варіантів системи доставки.

Основний матеріал дослідження. Згідно 3 принципами системного аналізу, існує три підходи до опису систем :

- морфологічний - внутрішній устрій системи;

- функціональний - аналіз діяльності системи, взаємодії іiі з середовищем і між частинами системи;

- інформаційний - аналіз міри невизначеності стану системи і його зміни.

Відмітимо, що усі три підходи до опису систем взаємозв'язані.

Відомо, що будь-яка система це можина елементів, які знаходяться в стосунках і зв'язках один з одним та утворюють деяку цілісність, єдність. I перед тим, як приступити до опису системи доставки вантажів, необхідно визначити, що саме $є$ iіi елементом.

Система доставки являє собою досить складну структуру, охарактеризувати яку можна з різних позицій. Наприклад, види транспорту, викори- 
стовувані технології, підприємства, що виконують певні операції в цій системі тощо. У зв'язку з багатоаспектністю процесу доставки за доцільне декомпозувати систему доставки на чотири рівні (рис. 1):
- топологія;

- вид транспортування;

- транспортно-технологічний процес;

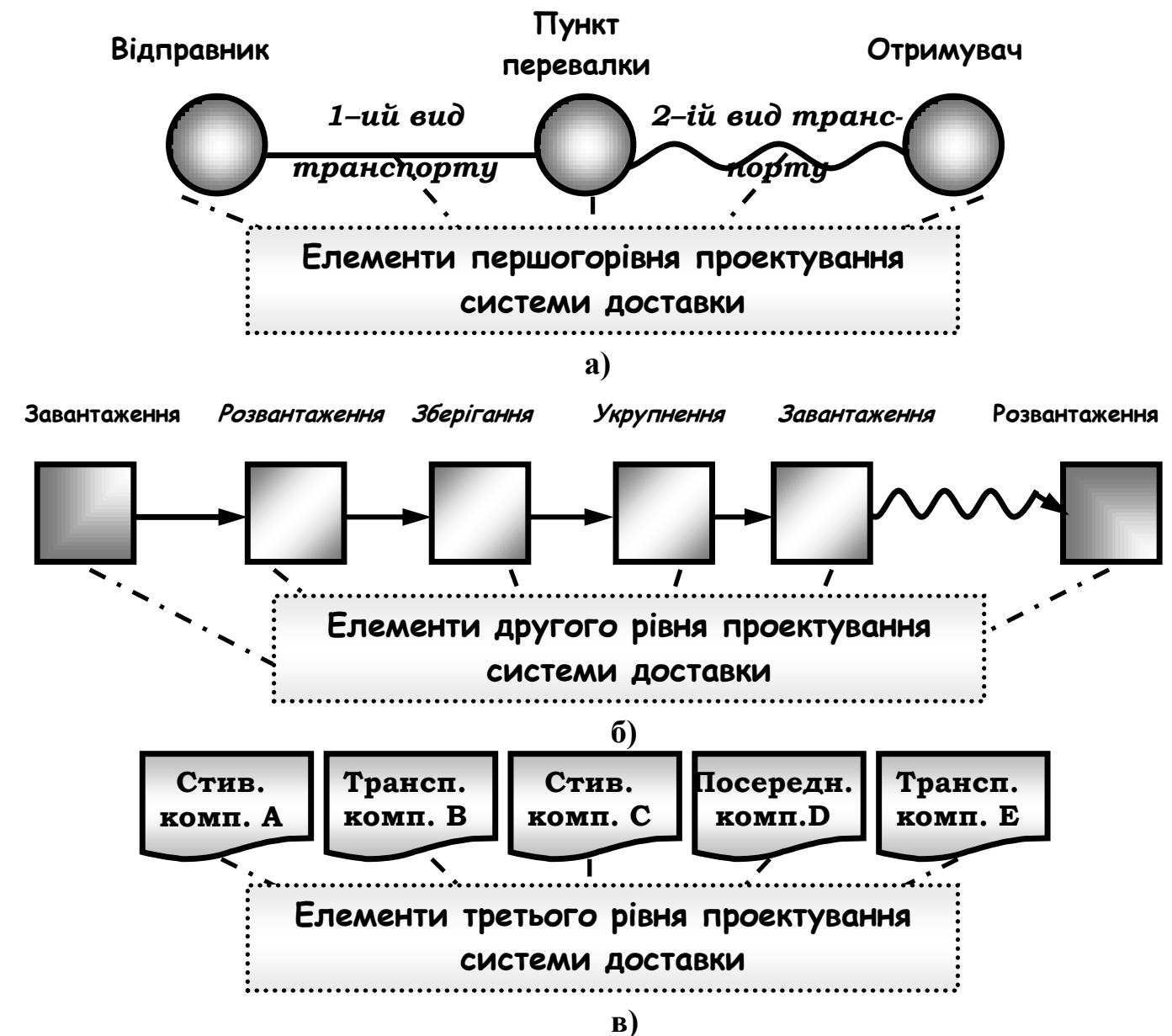

Рис. 1. Елементи системи доставки вантажів

Джерело: власна розробка автора

Наприклад, в якості елементів логістичної системи доставки нафти і нафтопродуктів Шутенко Т.M. у роботі [10] виділяє наступні:
1) нафтовидобувні підприємства (виробники нафти і нафтосховища);

2) оптові підприємства; 
3) транспорт і інфраструктура, що забезпечує функціонування транспорту;

4) збутові підприємства;

5) інформаційна підсистема;

6) матеріалопотоки нафти;

7) фінансові потоки.

Слід розрізняти поняття «логістична система» $\mathrm{i}$ «система доставки». У рамках логістичної системи вирішуються питання комплексного управління перетворюваними матеріальними потоками, включаючи їх переміщення. Система доставки, на наш погляд, $\epsilon$ певним «зрізом» логістичної системи, що охоплює виключно транспортні зв'язки між учасниками логістичної системи. Тобто, в системі доставки підприємства розрізняються не за профілем їх діяльності, а тільки як відправники і одержувачі вантажу, що знаходяться в певних географічних регіонах.

Рис. 2 відбиває наше бачення відношення системи доставки вантажів до логістичної системи.

На схемі рис. 2 а представлена принципова схема елементів логістичного ланцюга, об'єднаних рухом матеріального потоку.

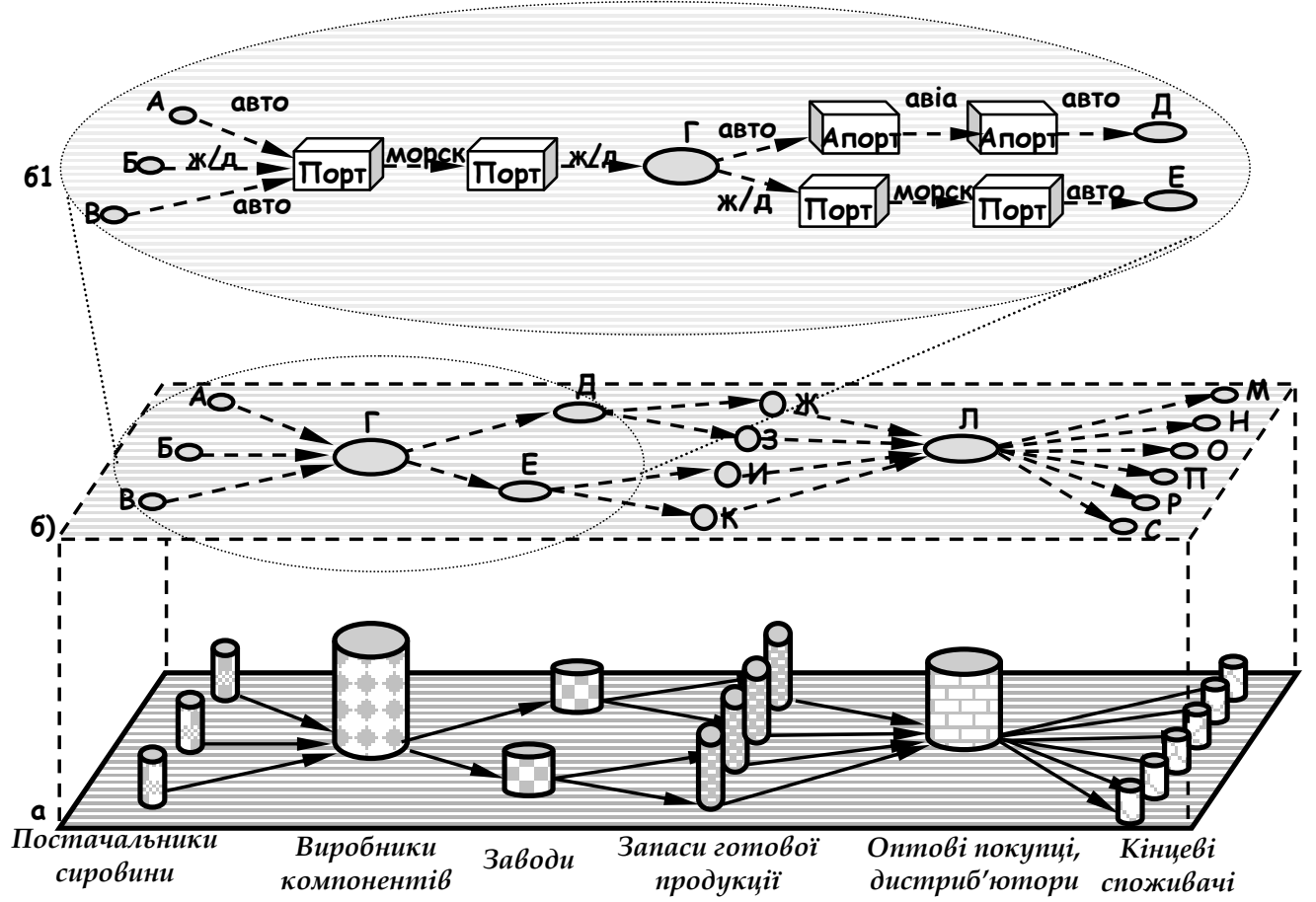

Рис. 2. Система доставки як зріз,

який включає тільки транспортні зв'язки логістичної системи

Джерело: власна розробка автора

На схемі рис. 2 б представлений погляд на логістичну систему 3 точки зору організатора транспорту90 вання, який розробляє різні варіанти доставки вантажу, один з яких представлений на детальнішій схемі 
рис. 2 б1. Причому організувати можна як увесь шлях руху матеріального потоку за схемою, так і на кожних окремо взятих ділянках - i в тому, і в іншому випадку це буде системою доставки - простої, або логістичною (згідно до [9]).

Таким чином, ми можемо говорити про те, що декомпозиція логістичної системи і системи доставки на елементи відбувається по-різному.

Логістичну систему утворюють одно або декілька підприємств, що шукають партнерів у потрібних їм сферах діяльності для ефективного просування матеріального потоку. В організації ж системи доставки з'являється необхідність тільки тоді, коли між двома або більше підприємствами ланцюга з'являється необхідність в перевезенні вантажу.

У такому разі, згідно 3 нашим представленням системи доставки [9], декомпозицію системи доставки на елементи необхідно проводити 3 позицій кожного рівня системи (рис. 3).

Так, на рівні «Вид транспортування», елементами системи доставки є пункти перевалки і види транспорту (рис. 3 a).

На рівні «Транспортно-технологічний процес» елементами системи доставки є набір послідовних операцій, сприяючих і супутніх переміщенню вантажу: завантаження/ вивантаження, транспортування, зберігання, укрупнення, тощо (рис. 3 б).

I на останньому рівні «Склад учасників» елементами системи доставки виступають юридичні і фізичні особи, що забезпечують виконання елементів перших двох рівнів системи доставки (рис. 3 в).
Таким чином, елементи системи доставки утворюють іiї структуpy, яка, як відомо, є сукупністю зв'язків і стосунків між частинами цілого, необхідними для досягнення мети. Розглянемо детальніше кожний 3 рівнів декомпозиції системи доставки.

Як відомо, основними типами топології (просторового розміщення елементів системи) структур системи є:

- лінійний;

- ієрархічний;

- мережевий;

- матричний.

Оскільки матеріальний потік має чітку географічну схему переміщення від вантажовідправників до вантажоодержувачів, то системи доставки мають лінійний або мережевий типи структур (рис. 4).

Таким чином, топологія систем доставки відбиває взаємозв'язок елементів першого рівня декомпозиції системи доставки, тобто пунктів перевалки вантажу.

Згідно до виконаної нами в [9] класифікації систем доставки, з точки зору широти охоплюваних логістичних процесів, ми виділили прості системи доставки (транспортування) i логістичні. Простим системам доставки відповідає лінійна структура, логістичним же - переважно мережева, хоча лінійна теж може мати місце. 
DEVELOPMENT OF MANAGEMENT AND ENTREPRENEURSHIP METHODS ON TRANSPORT, № 1 (70), 2020
РОЗВИТОК МЕТОДІВ

УПРАВЛІННЯ ТА ГОСПОДАРЮВАННЯ НА ТРАНСПОРТІ, № 1 (70), 20

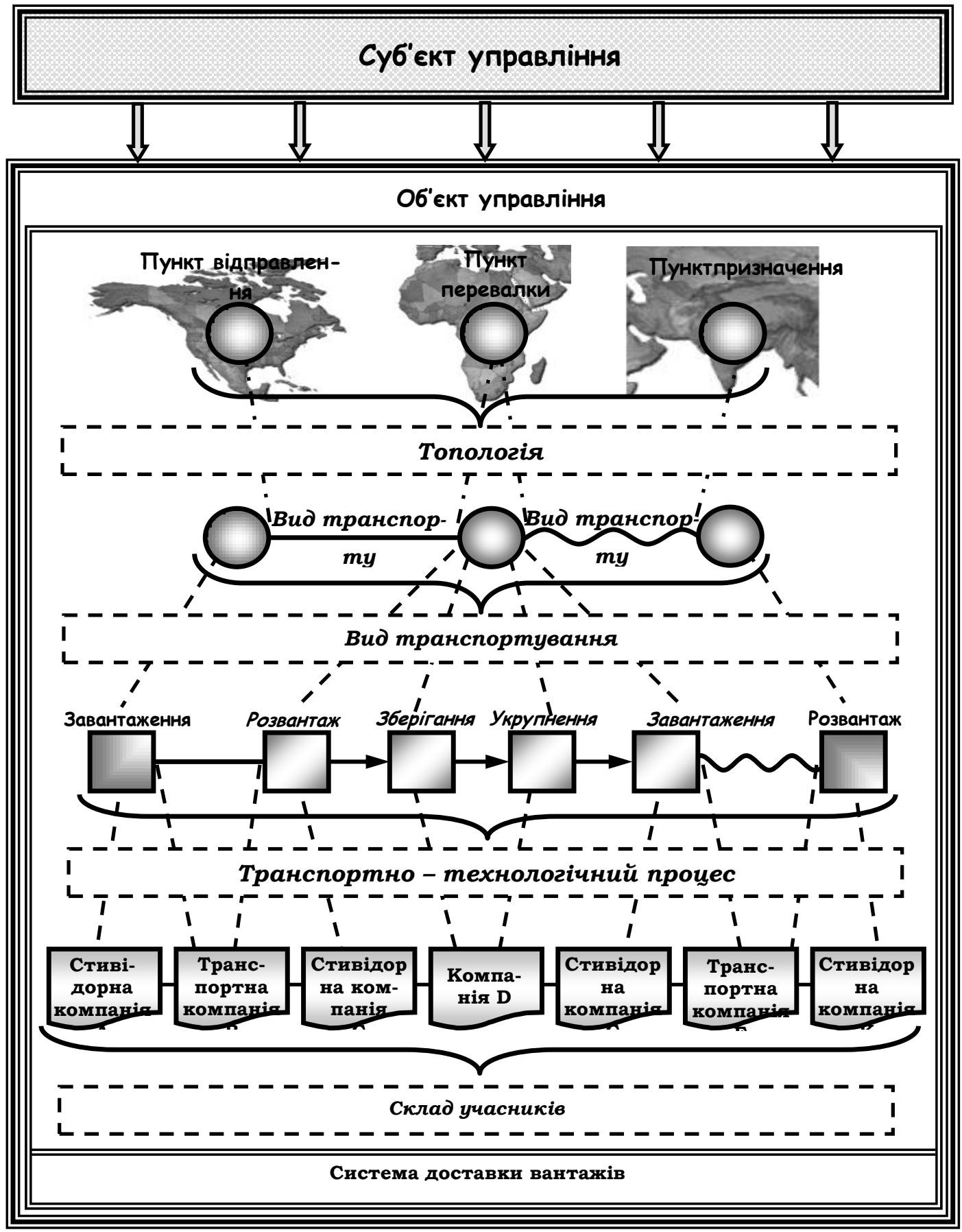

Рис. 3. Чотирирівневе уявлення системи доставки вантажів

Джерело: власна розробка автора 


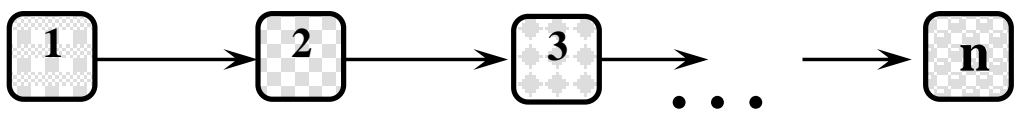

а) лінійна структура
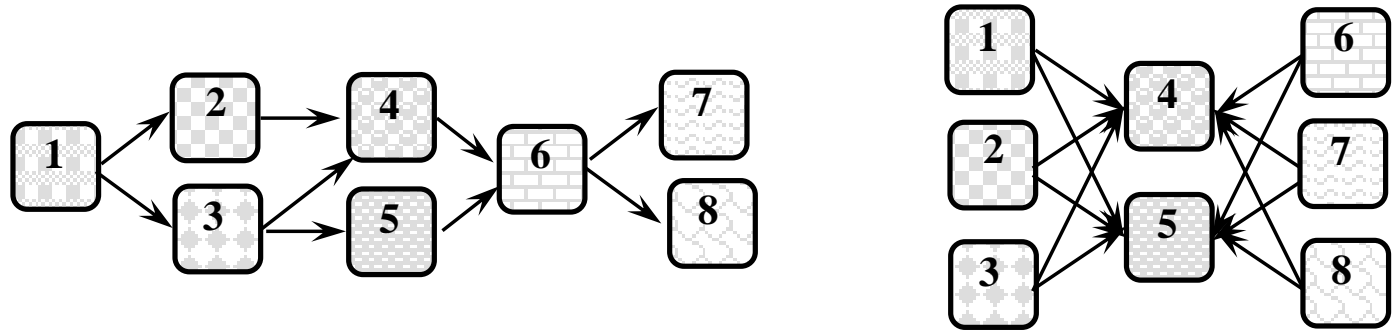

б) мережева структура

Рис. 4. Топологія системи доставки вантажів

\section{Джерело: власна розробка автора}

Як ми визначили вище, будьяка система доставки формується 3 множини елементів трьох рівнів, пов'язаних матеріальним потоком, що проходить через них, тільки природа цих зв'язків $є$ різною. На першому рівні це топологічні (географічні), на другому - технологічні, на третьому - функціональні (договірні) зв'язки.

Функціональний опис системи, як було сказано вище, це аналіз діяльності системи. Система доставки $€$ унікальною у своєму роді системою, тому і тут їй властиві деякі особливоcri.

Для того, щоб описати систему з точки зору виконуваних функцій, необхідно відмітити, що послідовні елементи першого і другого рівнів системи доставки можуть виконуватися як одним, так і декількома учасниками системи, тобто, елементами третього рівня. Як вказувалося в роботі [10], у логістичних системах доставки множини функцій учасників систем доставки можуть перетинатися, тобто одні і ті ж операції мо- жуть виконувати і виконують різні підприємства у рамках системи доставки.

Тут необхідно відмітити, що елементи, що $є$ операціями транспортно-технологічного процесу, 3 яких складається будь-яка система доставки, $з$ точки зору діяльності того або іншого підприємства, розглядаються як його функції. Наприклад, завантаження/розвантаження вантажу, що є елементом системи доставки, одночасно є функцією підприємства-учасника системи (рис. 5).

Тож, кожен учасник системи доставки виконує одну або декілька функцій, реалізовуючи один або декілька елементів транспортно-технологічного процесу системи. Таким чином, основна функція системи доставки - транспортування вантажу, що реалізується учасниками системи доставки за рахунок виконання кожним 3 них своїх прямих функцій і обов'язків, які утворюють впорядковану множину елементів транспортнотехнологічного процесу системи доставки. 


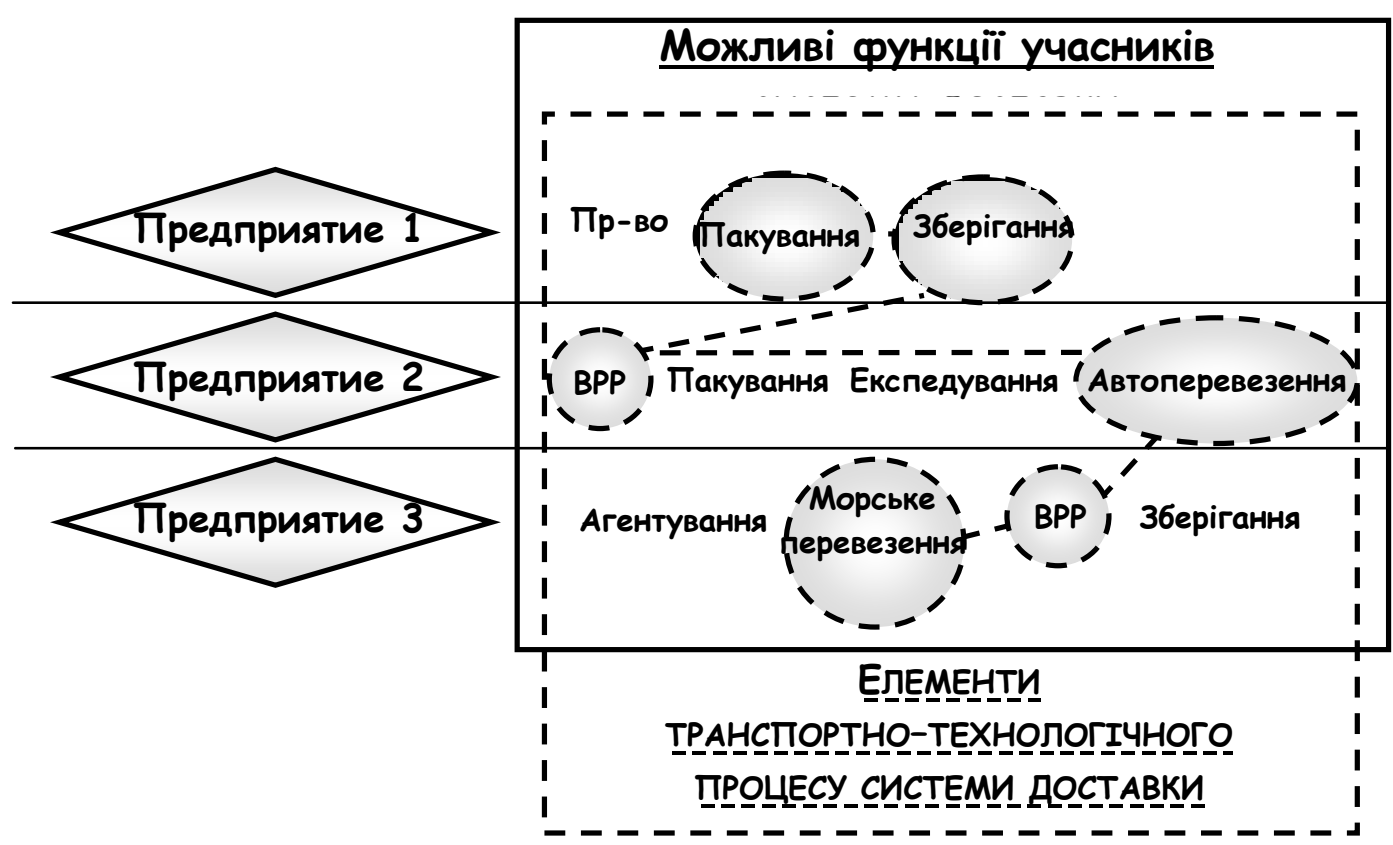

Рис. 5. Формування транспортно-технологічного процесу системи доставки вантажів з множини елементів

Джерело: власна розробка автора

Спираючись на запропоновані в [2] параметри, визначимо наступний набір критеріїв, по яких клієнт може визначати якість системи доставки вантажів.

Витрати (R). Перевага віддається варіанту системи доставки 3 мінімальними витратами, або витратами, що знаходяться в допустимих межах.

Час (Т). Від часу доставки безпосередньо залежать витрати за системою доставки в цілому.

Надійність (N). Найбільш важливими параметрами, що враховуються при оцінці надійності системи доставки є збереження, своєчасність, рівень ризику, імідж учасників системи, тощо.
Гнучкість (F). Тут під гнучкістю розуміється готовність підприємства виконувати зміни, можливість надання різних рівнів обслуговування, готовність до зміни фінансових умов платежу, кредиту, знижок, що вносяться клієнтом.

Комплексність (С). Чим ширше асортимент пропонованих послуг, тим вище рівень якості обслуговування. Проте, кількість послуг, що надаються, може бути велика, але необхідні послуги виявлятися не будуть. Тому, для оцінки комплексності послуг необхідно розглядати здатність системи на надання необхідної послуги.

Інформативність (I). Визначається здатністю системи дати клієнтам у будь-який момент часу ін- 
формацію про тарифи, умови доставки і про місце знаходження вантажу в процесі доставки і зберігання.

Доступність (А). На цей показник впливають два чинники зручність обслуговування і готовність до доставки.

Потужність (М). Для простих систем доставки, які займаються лише транспортуванням, потужність визначається провізною здатністю транспортних засобів і пропускною спроможністю перевалочних пунктів і може мати розмірність тонн/добу (тонн/рік). У логістичній системі доставки може бути найрізноманітніший склад учасників (наприклад, постачальники початкової сировини, виробники, споживачі, дистриб'ютори і так далі), але не усі з них будуть виконавцями якого-небудь елементу системи доставки (наприклад, підприємство виконує функцію виробництва продукції і $є$ учасником логістичного ланцюга, але виробництво не $\epsilon$ елементом системи доставки, тому виробник не забезпечує виконання одного з елементів системи доставки, але $\epsilon$ іiі учасником 3 точки зору топологіï). Тому, можна стверджувати, що для логістичної системи доставки потужність визначається тією кількістю вантажу, яка може бути прийнята i засвоєна подальшою ланкою в логістичному ланцюзі в одиницю часу.

Таким чином, система доставки може бути описана набором параметрів

$$
U=\langle R, T, N, F, C, I, A, P\rangle
$$

Позначимо $M=\left\{M^{i}, i=\overline{1, n}\right\}-$ множина елементів другого рівня декомпозиції системи доставки (див. рис. 2). Потужність кожного еле- менту - $P\left(M^{i}\right)$. Тоді, потужність системи доставки можна визначити, як $P=\min _{i} P\left(M^{i}\right)$.

Залежно від даного завдання, рівень декомпозиції може бути або за видом транспортування, або за транспортно-технологічним процесом, або за складом учасників.

Тобто, будь-яку систему доставки можна описати таким чином:

$$
C D=\langle M, G, U\rangle,
$$

де $M$ - елементи системи доставки, причому кожному елементу може відповідати декілька суб'єктів;

$G$ - орієнтований граф взаємозв'язків елементів $P_{i}$;

$U$ - набір параметрів системи доставки $U=\langle R, T, N, F, C, I, A, P\rangle$.

Таким чином, у результаті отримуємо кількісний і якісний опис системи доставки: перші два елементи в (2.15) відбивають топологію системи доставки, третій - параметри.

$\mathrm{У}$ роботі було виконано опис системи доставки вантажів згідно 3 трьома рівнями декомпозиції. На кожному $з$ рівнів визначені елементи системи доставки, а також визначений набір якісних і кількісних параметрів, який описує роботу елементів транспортно-технологічного рівня декомпозиції. Це дозволяє виділяти основні і другорядні параметри для кожного клієнта i, тим самим, варіювати ними для досягнення кращого результату. 


\section{СПИСОК ЛІТЕРАТУРИ}

1. Бенсон Д., Уойтхед Дж. Транспорт и доставка грузов / Пер. с англ. М.: Транспорт, 1990. 279 с.

2. Транспортная логистика. Под общей редакиией Л.Б. Миротина. М.: Экзамен, 2003. 512 c.

3. Логистика и управление цепями поставок: учебник и практикум для академического бакалавриата / В.С. Лукинский, В.В. Лукинский, Н.Г. Плетнева. М.: Издательство Юрайт, 2018. 359 с.

4. Лапкина И.А., Поддубная Н.Н. Ресурсы логистической системы // Вісник Східноукраїнського наџіонального університету ім. Володимира Даля. 2015. № 2(219). С. 69-72.

5. Модели и методы теории логистики: Учебное пособие. 2-е изд. Под ред. В.С. Лукинского. 2-е изд. СПб.: Питер, 2008. 448 с.

6. Логистика: учебник для академического бакалавриата / Ю.М. Неруш, А.Ю. Неруш. 5-е изд., перераб. и доп. М.: Изд-во Юрайт, 2019. 559 с.

7. Уотерс Д. Логистика. Управление иепью поставок / Пер. с англ. М.: Юнити, 2003. 503 c.

8. Эффективность логистического управления: Учебник для вузов / Под общ. ред. Л.Б. Миротина. М.: Издательство «Экзамен», 2004. 448 с.

9. Смрковская В.Ю. Классификация систем доставки грузов // Методи та засоби управління розвитком транспортних систем. Одеса: ОНМУ. 2004. № 9 .

10. Шутенко Т.Н. Методические основы проектирования логистической системы доставки грузов (на примере нефти и нефтепродуктов): Дис. канд. техн. наук: 05.22.01. Одесса, 2005.162 c.

11. Оспіщев B.І., Пруненко Д.О., Бурко Д.Л., Срмак О.М., Санько Я.В. Дослідження операчій: Навчальний посібник / За ред. B.I. Оспіщева. Харків: ХНАМГ, 2008. 136 с.

12. Орловський П.Н. Системный анализ (основные понятия, принципь, методология). К.: ІЗМН, 1996. $360 \mathrm{c.}$

13. Логистика снабжения: учебник для бакалавриата и магистратуры / В.И. Сергеев, И.П. Эльямевич / Под общ. ред. В.И. Сергеева. 2-е изд., перераб. и доп. М.: Изд-во Юрайт, 2014. 523 c.

14. MacCarthy B., Blome C., Olhager J., Zhao X., Singh Srai J. Supply Chain Evolution - Theory, Concepts and Science / International Journal of Operations \& Production Management. April 2016. DOI: 10.1108/IJOPM-022016-0080 (https://www.researchgate.net/publication/ 301891078_Supply_ Chain_Evolution_-_Theory_Concepts_and_Science)

15. Mazzola E., Bruccoleri M., Perrone G. Supply chain of innovation and new product development / Journal of Purchasing and Supply Management 21(4) April 2015. DOI: 10.1016/j.pursup.2015.04.006(https:// www. researchgate. net/publication/276074859_Supply_chain_of_ innovation_and_new_product_development) 
16. Lapkina I.O., Malaksiano M.O. Modelling and optimization of perishable cargo delivery system through Odesa port // Actual Problems of EconomicsVolume 177, Issue 3, 1 January 2016, Pages 353-365.

\section{REFERENCES}

1. Benson D. \& Whitehead G. (1990). Transport and distribution. M.: Transport, 279 [in Russian].

2. Mirotin, L.B. (2003). Transportnaya logistica [Transport logistics]. M.: Ekzamen, 512 [in Russian].

3. Lukinskiy, V.S., Lukinskiy, V.V. \& Pletneva, N.G. (2018). Logistica i upravleniye tsepiami postavok [Logistics and supply chain management]. M.: Izdatelstvo Urait, 359 [in Russian].

4. Lapkina, I.A. \& Poddubnaia, N.N. (2015). Resursy logisticheskoy sistemi [Logistics System Resources]. Visnyk Skhidnoukrayins'koho natsional'noho universytetu imeni Volodymyra Dalya - Visnik of the Volodymyr dahl east Ukrainian national university. № 2(219), 69-72 [in Ukrainian].

5. Modeli i metodi teorii logistiki [Models and methods in logistics theory] (2008). Uchebnoeposobie. 2 izd. Podred. V.S. Lukinskogo, SPb.: Piter, 448 [in Russian].

6. Nerush, U.M. \& Nerush, A.U. (2019). Logistica [Logistics]. 5 izd., pererab. $i$ dop. M.: Izdatelstvo Urait, 559 [in Russian].

7. Waters, D. (2003). Logistica. Upravlenie tsepiu postavok [Logistics. Supply chain management]. M.: Unity, 503 [in Russian].

8. Mirotin, L.B. (2004). Effectivnost logisticheskogo upravlenia [Efficiency of logistics management]. M.: Izdatelstvo Ekzamen, 448 [in Russian].

9. Smrkovska, V.U. (2004). Klassificatsia system dostavki gruzov [Classification of goods delivery systems]. Metodi ta zasobi upravlinnia rozvutkom transportnich system - Methods and tools for managing the development of transport systems. Odessa: ONMU, № 9 [in Russian].

10. Shutenko, T.N. (2005). Metodicheskie osnovi proektirovania logisticheskoi sistemi dostavki grusov (na primere nefti i nefteproductov) [Methodological founds of engineering the logistics systems of goods delivery (on example of oil and oil-products]: Diss. kand. techn. nauk: 05.22.01. Odessa, 162 [in Russian].

11. Osiptsev, V.I., Prunrnko, D.O., Burko, D.L., Ermak, O.M. \& Sanko, Y.V. (2008). Dosligjennia operatsiy [Operations research]. Kharkiv: XNAMG, 136 [in Russian].

12. Orlovskiy, P.N. (1996). Sistemniy analiz (osnovnie poniatiya, printsipi, metodologia) [System analysis (basic concepts, principles, methodology)]. K.: IZMN, 360 [in Russian].

13. Sergeev, V. I. \& Eliashevich, I. P. (2014). Logistica snabjenia [Suplly logistics]. M.: IzdatelstvoUrait, 523 [in Russian]. 
14. MacCarthyB., Blome C., Olhager J., ZhaoX. \& SinghSrai, J. (2016). Supply Chain Evolution - Theory, Concepts and Science. International Journal of Operations \& Production Management. Retrieved from https://www. researchgate.net/publication/301891078_Supply_Chain_Evolution_-_ Theory_Concepts_and_Science

15. Mazzola, E., Bruccoleri, M. \& Perrone, G. (2015). Supply chain of innovation and new product development. Journal of Purchasing and Supply Management Volume 21, Issue 4. Retrieved from https://www. researchgate.net/publication/276074859_Supply_chain_of_innovation_and_ne w_product_development

16. Lapkina, I.O. \& Malaksiano, M.O. (2016). Modelling and optimization of perishable cargo delivery system through Odesa port. Actual Problems of Economics Volume 177, Issue 3, 353-365.

Стаття надійшла до редакиії 20.02.2020

Посилання на статтю: Смрковська В.Ю. Чотирирівнева декомпозиція систем доставки вантажів з визначенням основних критеріїв функціонування // Розвиток методів управління та господарювання на транспорті: Зб. наук. праць, 2020. №1 (70). С. 86-98. DOI 10.31375/2226-1915-2020-1-86-98.

Article received 20.02.2020

Reference a JournalArtic: Smrkovska, V. (2020). Four-level decomposition of cargo delivery systems with the definition of basic functioning criteria. Development of management and entrepreneurship methods on transport. 1 (70), 86-98. DOI 10.31375/2226-1915-2020-1-86-98. 